\title{
Social Media, Gender and Architectures Canon
}

HARRIET HARRISS

Royal College of Art 
Decolonising the curriculum demands curricula and pedagogic change across all academic disciplines. Whereas the contents of architecture may well be epistemologically diverse, the recognized producers of architecture are determinedly less diverse resulting in calls to reconsider who gets to determine what architecture contains. To challenge this, a broader body of knowledge inclusive of gender, class and race is needed, one that responds to both nascent change and persistent instability, and yet remains 'live' - able to adapt to new authors and new audiences as they arise. To generate this knowledge, how we capture and collect it needs to be reimagined too, and the neutral normative, westernized and gendered ideologies and values that persist within architecture's canon, directly confronted. As both the \#BlackLivesMatter and \#MeToo movement has demonstrated, social media has provided a rapid response platform through which knowledge is created, communicated and contested. This presentation critically reflects upon the problems and possibilities underpinning three, social-media situated initiatives that sought to repatriate women's contribution to the canon of architecture. It describes, (1) the production of a crowd-authored list of women architecture writers (2) crowd-sourcing an alternative list of women architects eligible for the \#RIBAgoldmedal by Part W and, (3) a crowd-funded, 'women architects of the world' Top Trump card game. Each of these tactics raise questions about the efficacy of social media platforms such as Twitter and Facebook that have otherwise been heralded as the defining tool of fourth wave feminism [1], when in reality, these spaces are statistically more likely to, 'elevate misogyny to entirely new levels of violence and virulence.' [2] The presentation will consider whether adopting non-normative modes for content collation, curation and communication are successful in disrupting gendered ideologies and values, and the pedagogical and professional implications of for doing so.

1 Grady, Constance. 'The waves of feminism, and why people keep fighting over them, explained',Vox, July 20, 2018

2 Zuckerberg, Donna. Not All Dead White Men: Classics and Misogyny in the Digital Age. Harvard University Press, 2018 Women Write Architecture: tinyurl.com/y4uz98vt, tinyurl. com/yczck79y

Part W \#RIBAGoldMedal: tinyurl.com/y3enfv65

Top Trumps: tinyurl.com/y5rx7aww 

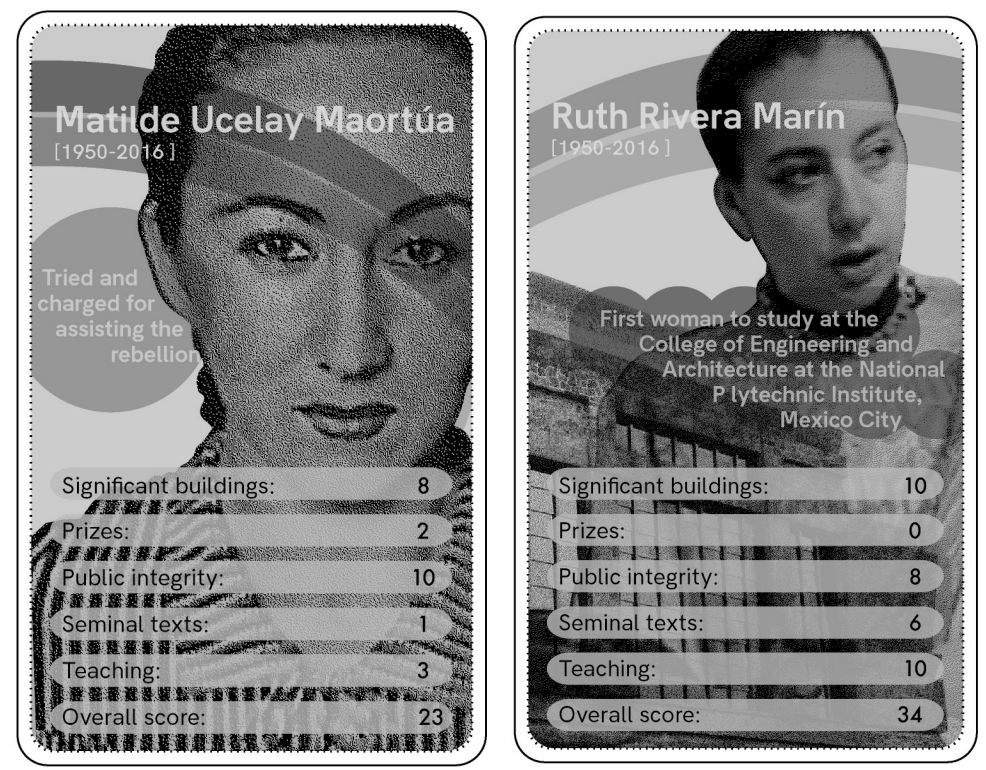

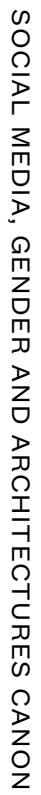

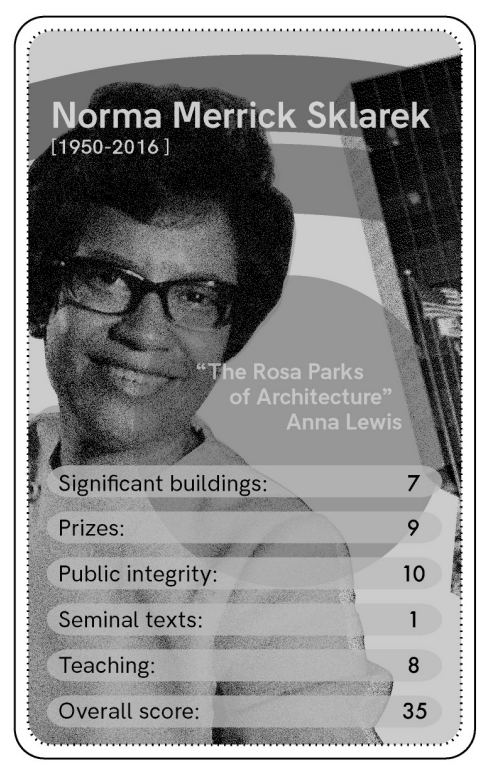



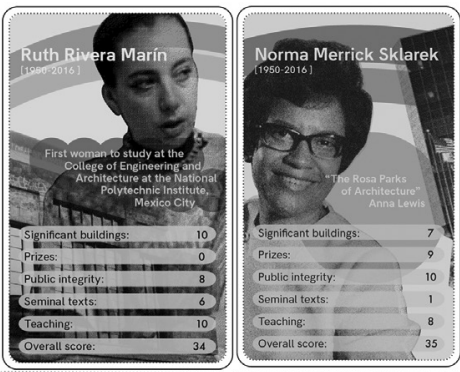

Ruth Rivera Marín Mexico - [1927-1969]

FiRST: Woman to study architecture at the

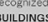

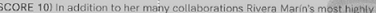

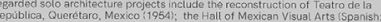

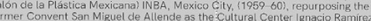

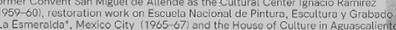
$x$
exico 11969

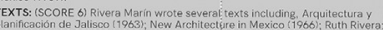

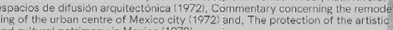

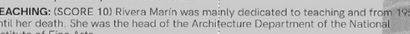

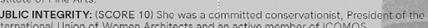

18042019

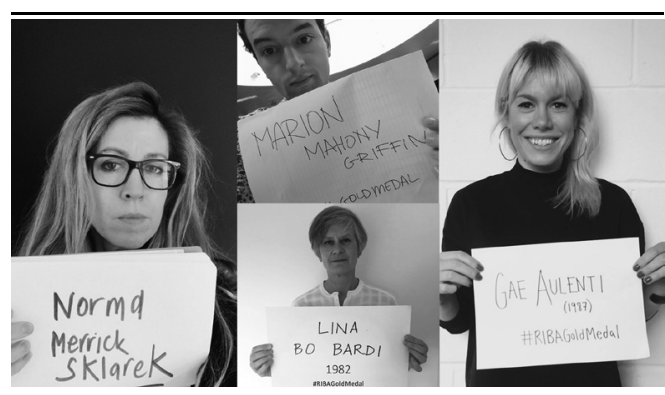

Part W invites architects to create alternative all-female Royal Gold Medal winners list

\section{๑ㅇ (1)}

Tom Ravenscroft | 15 February 2019

Leave a comment

Women's action group Part $\mathrm{W}$ is crowdsourcing suggestions of worthy women to create an allfemale alternative to the predominately male RIBA Royal Gold Medal winners list.

Coinciding with this year's medal being presented to Nicolas Grimshaw, Part W has launched the campaign to highlight the fact that there has only been one woman as sole winner of the RIBA Royal Gold Medal in its 171-year history.

The collective, which was founded by Zoë Berman of London-based Studio Berman, is asking people to suggest women that they think would be worthy winners of the Gold Medal.

"Playful way to draw attention to important issue"

"From today we're inviting people from across the industry and those working in engineering urban design, planning and education to nominate ideas for people whom they'd like to see celebrated on an alternative list that would award women - back to 1848 - who have made a significant contribution to the built environment," Berman told Dezeen.

"It's meant to be a tongue-and-cheek, playful, way to draw attention to what is an important and serious discussion." 